УДК 373.3.016:51(07)

DOI: https://doi.org/10.35619/iiu.v0i9.120

Сілкова Ельвіра

старший викладач

кафедри математики з методикою викладання

Рівненського державного гуманітарного університету,

м. Рівне, Україна

ORCID:0000-0002-2595-0606

e-mail: esilkova69@gmail.com

\title{
ТЕОРЕТИКО-МЕТОДИЧНІ ОСНОВИ ФОРМУВАННЯ У МАЙБУТНІХ ВЧИТЕЛІВ ПОЧАТКОВОЇ ШКОЛИ ЗАГАЛЬНИХ ПРИЙОМІВ РОБОТИ НАД СЮЖЕТНИМИ ЗАДАЧАМИ
}

\begin{abstract}
Анотація. У статті обгрунтовано, що в новій редакції «Навчальних програм для загальноосвітніх навчальних закладів» особливо значущу роль відведено в курсі навчання математики змістовій лінії «Сюжетні задачі». Метою цієї змістової лінії $\epsilon$ формування в учнів загального вміння працювати над задачею, розв'язувати задачі певних видів. Встановлено, що сюжетні задачі $\epsilon$ ефективним засобом навчання і розвитку учнів. Задачі в початковому курсі математики, з одного боку, $\epsilon$ специфічним розділом програми, який мають засвоїти учні, а 3 другого виступають як дидактичний засіб навчання, виховання і розвитку школярів. Отже, задачі дозволяють моделювати практичні ситуації, показувати зв'язок математики із життям. У статті розглядаються теоретико-методичні основи формування загальних прийомів роботи над сюжетними задачами у майбутніх вчителів початкової школи. 3 метою уникнення недоліків у формуванні уміння розв'язувати задачі запропоновано дотримуватися таких етапів роботи над будь-якою задачею: 1) ознайомлення школярів з умовою задачі; 2) перевірка засвоєння учнями змісту задачі; 3) проведення аналізу задачі або відшукання шляхів ії розв’язання; 4) складання плану розв'язання задачі; 5) запис розв'язання задачі; 6) робота над розв'язаною задачею. Проаналізовано кожний етап роботи над задачами. Проілюстровано схеми аналітичного та синтетичного способів аналізу задач. Сутність роботи вчителя з використанням того чи іншого способу аналізу задачі продемонстровано на прикладі такої задачі: «На митницю приїхало для розмитнення 8 вантажних і 5 легкових автомобілів. 9 автомобілів вже оформили необхідні документи. Скільком автомобілям ще залишилося оформляти документи?». Представлені записи коротких умов та розв'язання задач різними способами, а також система вправ щодо формування умінь розв'язувати сюжетні задачі. Аби допомогти дітям віднайти правильний шлях розв'язання задачі, запропоновано різні варіанти завдань.
\end{abstract}

Ключові слова: задача, етапи роботи над задачею, коротка умова, аналітичний та синтетичний способи аналізу задач, схема, план розв'язування задачі, розв'язання.

Постановка проблеми. Останнім часом, у зв'язку з поширенням ідей впровадження нової української школи, все частіше звертаються до теми навчання через задачі. Реформування початкової математичної освіти в Україні $€$ частиною процесу модернізації освітньої системи на засадах компетентнісного підходу. Ці зміни стосуються створення нових освітніх 
стандартів, оновлення і перегляду навчальних програм, змісту навчальнодидактичних матеріалів, підручників, створення сучасних засобів навчання. Формування у школярів ключових і предметних компетентностей значною мірою залежить від рівня як математичної, так і методичної підготовки вчителя початкових класів.

У новій редакції «Навчальних програм для загальноосвітніх навчальних закладів» зазначено, що важливу роль у формуванні компетентності учня відіграє розвиток здатності розпізнавати практичні проблеми, які можна вирішувати за допомогою застосування математичних методів. 3 огляду на це особливо значущу роль відведено в курсі навчання математики змістовій лінії «Сюжетні задачі». Метою цієї змістової лінії $\epsilon$ формування в учнів загального вміння працювати над задачею, розв'язувати задачі певних видів. Сюжетні задачі, як ніякий інший учбовий матеріал, здатні здійснити таке навчання на практиці, оскільки дозволяють створювати проблемні ситуації на уроках; сюжетні задачі $\epsilon$ ефективним засобом навчання і розвитку учнів. Задачі в початковому курсі математики, з одного боку, становлять специфічний розділ програми, який мають засвоїти учні, а 3 другого - виступають як дидактичний засіб навчання, виховання і розвитку школярів (Міністерство освіти і науки України, 2018). Отже, задачі дають змогу моделювати практичні ситуації, показувати зв'язок математики із життям.

Аналіз останніх досліджень 3 проблеми. Реалізація вимог Державного освітнього стандарту та навчальних програм 3 математики щодо сюжетних задач залежить від сформованості у майбутніх вчителів початкової школи уміння навчати учнів розв'язувати їх. Проблема навчання розв'язувати математичні задачі, зокрема й сюжетні, привертала увагу М. О. Бантової, М. В. Богдановича, С. О. Скворцової, Ю. М. Колягіна, Л. М. Фрідмана, Т. М. Хмари та ін. Автори вивчають зміст поняття «задача», досліджують іiі структуру, виділяють етапи іiі розв'язання, описують застосовані при цьому методи і прийоми, будують різноманітні класифікації задач. Заслуговують на увагу ряд дисертаційних досліджень, які розкривають проблему навчання молодших школярів розв'язувати задачі. Удосконаленню системи математичних задач для початкових класів присвячено дисертаційне дослідження Г. П. Лишенка. Методику формування у молодших школярів уміння розв'язувати сюжетні задачі в системі розвиваючого навчання вивчали Н.Б.Істоміна, В.В.Малихіна, формування вмінь учнів початкової школи розв'язувати сюжетні задачі із застосуванням диференційованого підходу досліджувала В. А. Мізюк. На відміну від В. А. Мізюк, яка розглядала принципи відбору задач, диференційованих за складністю, О.В.Барінова вивчала можливості диференціації діяльності учнів в процесі розв'язування однієї і тієї ж задачі. Психологічні особливості функцій і способів формування у молодших школярів уміння розв'язувати арифметичні задачі на матеріалі традиційного i експериментального навчання вивчав В. В. Слугін. Л. В. Дяченко досліджувала психологічні особливості взаємодії вчителя і учнів молодших класів при розв'язанні «важких» мисленевих (математичних) задач.

Вчені, які досліджували проблему навчання молодших школярів розв'язувати задачі, майже не розкривають сутності підготовки майбутніх вчителів початкової школи до формування компетентностей, пов'язаних із навчанням учнів розв'язувати сюжетні задачі. Отже, хоча в психологічній та методичній науці існують деякі пропозиції щодо формування у майбутніх 
вчителів таких компетентностей, проте дотепер вони не набули детальної розробки на матеріалі конкретних видів задач.

Мета статті. Мета нашого дослідження полягає у тому, щоб розкрити сутність підготовки майбутніх вчителів початкових класів до навчання учнів розв'язувати сюжетні задачі, зокрема до засвоєння ними загальних прийомів роботи над задачами. Ми виходимо з припущення про те, що результативність навчання розв'язувати сюжетні задачі підвищиться за умови сформованості у майбутніх вчителів початкової школи теоретико-методичних основ формування у молодших школярів компетентності з розв'язування сюжетних задач.

Виклад основного матеріалу дослідження. Відповідно до теоретикометодичних основ формування компетентностей, пов'язаних 3 умінням розв'язувати сюжетні задачі, робота вчителя над будь-якою задачею передбачає дотримання таких етапів: 1) ознайомлення школярів 3 умовою задачі; 2) перевірка засвоєння учнями змісту задачі; 3) проведення аналізу задачі або відшукання шляхів іiі розв'язання; 4) складання плану розв'язання задачі; 5) запис розв'язання задачі; 6) робота над розв'язаною задачею. Пропуск хоча б одного 3 цих етапів може призвести до недоліків у формуванні уміння розв'язувати задачі. (Богданович, Козак та Король, 2008). Майбутній вчитель початкової школи повинен усвідомлювати специфіку і призначення кожного із етапів та повинен довести їх сутність до свідомості учнів у процесі навчання їх розв'язувати задачі.

Етап ознайомлення школярів 3 умовою задачі. Аналіз методичної літератури та досвіду роботи вчителів дають підстави твердити, що ознайомлення із змістом задачі можна провести одним із трьох способів: 1) задачу читає вчитель; 2) задачу читає один учень, а решта слідкують за текстом; 3) задачу читає кожен учень самостійно. Використання того чи іншого способу ознайомлення із змістом задачі обумовлюється сформованістю навички читання учнів класу. Завдання вчителя на цьому етапі полягає в тому, щоб навчити учнів правильно читати текст задачі, виділяючи наголосом відомі та шукані величини, а також зв'язки між ними. Такий підхід значно полегшить роботу на наступних етапах. Зазначимо, що для кращого усвідомлення змісту необхідно використовувати короткий запис умови задачі, складання схем, таблиць чи моделей. (Богданович, 1990). Водночас, зауважимо, що відповідно до висновків психологів, як тільки схеми, таблиці i моделі стають недоцільними, то від використання варто відмовитися. Це слід зробити тоді, коли така робота гальмує розвиток абстрактного і логічного мислення.

Етап перевірки засвосння учнями змісту задачі полягає в тому, аби вчитель переконався, що учні усвідомили зміст задачі та зв'язки між відомими та шуканими величинами. 3 цією метою вчитель може запропонувати учням повторити умову задачі, запитання задачі, всю задачу (правильні відповіді свідчитимуть про усвідомленість учнями таких понять як задача, умова задачі, запитання задачі). Також вчитель може на цьому етапі використати систему запитань такого виду: скільки ...?, що відомо про ...? Що слід визначити в задачі? Важливо, щоб відповіді учнів на поставлені запитання були повними, бо це сприятиме розвитку мовлення. На жаль, у практиці роботи вчителів трапляються непоодинокі випадки, коли вчителі формулюють запитання так: про що йдеться в задачі? Завдяки цьому будь-яка відповідь, наприклад, про 
овочі, про машину, про дітей тощо буде правильною, але не наближатиме школярів до знаходження шляху розв'язання задачі.

Етап аналізу задачі або відшукання шляхів ії розв'язання. Спостереження за роботою вчителів дозволяє констатувати, що доволі часто вони пропускають цей етап роботи, особливо при роботі з простими задачами. Зокрема, поставивши запитання: хто знає, як розв'язати задачу, - та отримавши від одного із учнів правильну відповідь, вчитель пропонує йому йти до дошки і записувати розв'язання задачі, а решті учням пропонується списувати. Сутність іншого недоліку полягає в тому, що вчитель об'єднує перший та другий етапи. Такі підходи спричиняють значні труднощі при навчанні учнів розв'язувати складені задачі.

Методисти виділяють два способи аналізу або відшукання способу розв'язування задачі: аналітичний, коли міркування йде від запитання до умови, та синтетичний, коли міркування йде від умови до запитання. (Скворцова, 2013). У методичній літературі не існує єдиної точки зору на те, яким способом проводити аналіз сюжетної задачі. Обирати спосіб аналізу, необхідно враховувати індивідуальні психологічні особливості та математичну підготовленість учнів класу. Аналітичний спосіб аналізу розпочинається запитанням «що необхідно знати, щоб дати відповідь на запитання задачі?», а синтетичний - «що можна визначити, якщо відомо, що ...?».

Сутність роботи вчителя з використанням того чи іншого способу аналізу задачі продемонструємо на прикладі такої задачі: «На митницю приїхало для розмитнення 8 вантажних і 5 легкових автомобілів. 9 автомобілів вже оформили всі необхідні документи. Скільком автомобілям ще залишилося оформляти документи?». Зазначимо, що при високому рівні математичної підготовки класу краще використати аналітичний спосіб або спосіб аналізу задачі від запитання до умови. Провести його варто у такий спосіб: що необхідно знати, аби дати відповідь на запитання задачі? Треба знати загальну кількість автомобілів і кількість автомобілів, які оформили всі необхідні документи. Досить часто вчителі задовольняються такою відповіддю дітей: треба знати загальну кількість автомобілів. Це неправильно, адже задачу «На митницю приїхало 13 автомобілів. Скільки автомобілів оформили всі документи?» розв'язати неможливо. Отже, вчитель повинен слідкувати за тим, щоб відповідь містила відомості про дві величини чи про одну та зв'язок між ними. Далі вчитель проводить наступну роботу: які із цих даних нам відомі? (дев'ять автомобілів вже оформили всі необхідні документи). Які із цих даних нам невідомі? - (загальна кількість автомобілів). Що необхідно знати, аби визначити загальну кількість автомобілів? - (кількість вантажних і легкових автомобілів). Чи відомі нам ці дані?, - так: 8 вантажних і 5 легкових автомобілів.

Синтетичний спосіб аналізу задачі можна провести так: що можна визначити, якщо відомо, що на митницю прибуло 8 вантажних і 5 легкових автомобілів? - Що можна визначити за цими даними? - загальну кількість автомобілів.

Зазначимо, що досить часто учні, які не до кінця усвідомили зміст задачі, можуть дати ще два варіанти відповідей: на скільки більше вантажних автомобілів прибуло на митницю чи на скільки менше легкових автомобілів прибуло на митницю. Непоодинокі випадки, коли вчителі говорять їм неправильно. Робити цього не можна, бо така відповідь на поставлене 
запитання правильна. Саме тому вчитель повинен запитати, а що ще можна визначити за цими даними. Завдяки такому підходу школярі привчатимуться до грунтовного аналізу математичних відношень.

Наступний етап роботи проводиться так: що можна визначити, якщо відомо загальну кількість автомобілів та якщо відомо, що документи оформили 9 автомобілів? Скільком автомобілям ще залишилося оформляти документи.

При формуванні у майбутніх вчителів уміння навчати учнів розв'язувати сюжетні задачі корисно використовувати схеми аналітичного та синтетичного способів аналізу задач. (Коваль та Скворцова, 2011). Такі схеми можна вивісити у класі як опорні для учнів.

2.

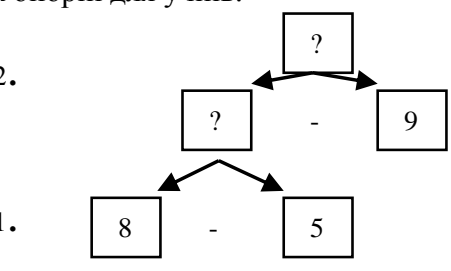

Схема аналітичного способу аналізу сюжетних задач.

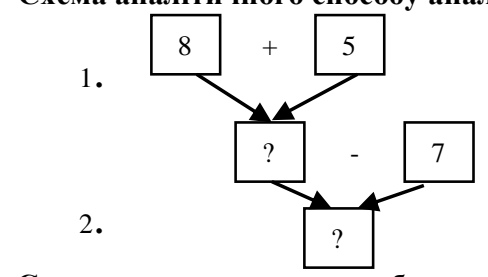

Схема синтетичного способу аналізу сюжетних задач.

Етап складання плану розв'язування задачі. Цю роботу слід провести, принаймні, так: що будемо визначати у першій дії? Будемо визначати загальну кількість автомобілів, які приїхали на митницю. Як це будемо робити? До кількості вантажних автомобілів додамо кількість легкових автомобілів (вчитель повинен вимагати саме такої відповіді, а не до 8 додамо 5!). Що будемо визначати у другій дії? Кількість автомобілів, яким ще потрібно оформити документи. Як це будемо робити? - Від загальної кількості автомобілів віднімемо кількість автомобілів, що оформили митні документи.

Етап запису розв'язання задачі. У методичній літературі зустрічаються способи запису розв’язання задач, які представлені у таблиці № 1 (Богданович, 1990). Після запису розв'язання задачі вчитель повинен запитати учнів: чи дали ми відповідь на запитання задачі? 3 метою особистісної орієнтації при формуванні умінь розв'язувати сюжетні задачі можна запропонувати тим школярам, які володіють добрими навичками письма або мають добру математичну підготовку, записати розв'язання різними способами. 
Таблиця 1

Різні способи запису розв'язання задач

\begin{tabular}{|c|c|c|c|}
\hline $\begin{array}{c}\text { Запис } \\
\text { розв'язання по } \\
\text { діях }\end{array}$ & $\begin{array}{c}\text { Запис } \\
\text { розв'язання по } \\
\text { діях } 3 \text { коротким } \\
\text { поясненням }\end{array}$ & $\begin{array}{c}\text { Запис } \\
\text { розв'язання } \\
\text { виразом }\end{array}$ & $\begin{array}{c}\text { Запис розв'язання по } \\
\text { діях із запитаннями }\end{array}$ \\
\hline $\begin{array}{l}\text { 1) } 8+5=13 \text { (авт.) } \\
\text { 2) 13-9=4 (авт.) } \\
\text { Відповідь: } \\
4 \quad \text { автомобілям } \\
\text { залишилося } \\
\text { оформляти } \\
\text { документи. }\end{array}$ & $\begin{array}{l}\text { 1) } 8+5=13 \text { (авт.)- } \\
\text { прибуло } \\
\text { автомобілів } \\
\text { митницю. } \\
\text { 2) } 13-9=4 \text { (авт.) - } \\
\text { залишилося } \\
\text { автомобілів. } \\
\text { Відповідь: } \\
4 \quad \text { автомобілям } \\
\text { залишилося } \\
\text { оформляти } \\
\text { документи. }\end{array}$ & $\begin{array}{l}(8+5)-9=4 \text { (авт.) } \\
\text { Відповідь: } \\
4 \quad \text { автомобілям } \\
\text { залишилося } \\
\text { оформляти } \\
\text { документи. }\end{array}$ & 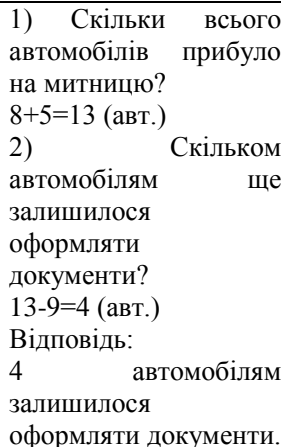 \\
\hline
\end{tabular}

Етап роботи над розв'язаною задачею може включати перевірку правильності розв'язання задачі, складання оберненої задачі, складання схожої задачі, заміну запитання чи сюжету задачі тощо.

Значні труднощі в учнів викликає перехід від розв'язування простих сюжетних задач до складених. Основною метою уроку ознайомлення дітей із першою складеною текстовою задачею $€$ формування свідомого розуміння ними основних відмінностей складеної задачі від простої. Аналіз психологопедагогічної та методичної літератури, спостереження за роботою вчителівноваторів дають підстави для твердження, що не існує єдиної загальноприйнятої думки щодо структури першої складеної задачі, 3 якою ознайомлюються діти. Тож, можна зосередити увагу на принаймні таких двох думок.

Одні методисти вважають, що перша складена задача повинна містити в собі дві простих задачі, одна $з$ яких є задачею на знаходження суми, а друга на знаходження остачі. Наприклад: «На митницю приїхало для розмитнення 8 вантажних і 5 легкових автомобілів. 9 автомобілів вже оформили всі необхідні документи. Скільком автомобілям ще залишилося оформляти документи?».

Інші методисти вважають, що першою потрібно вводити складену задачу, до якої входять також дві прості. Але одна з них є задачею на зменшення числа на кілька одиниць, що сформульована у прямій формі, а інша $є$ задачею на знаходження суми. Наприклад: «У Миколки було 8 моделей вантажних автомобіля, а легкових - на 2 автомобіля менше. Скільки всього моделей автомобілів було у Миколки?».( Богданович, Козак та Король 2008). Спільним для обох підходів $\epsilon$ те, що при ознайомленні $з$ першою складеною задачею використовують таку, при розв'язуванні якої слід використати дві різні дії. Відмінним у цих задачах $є$ те, що при першому підході використовують задачу, яка містить три даних, а в другому - задачу, яка містить двоє даних. Саме тому краще використовувати при ознайомленні учнів з першою складеною задачею таку, яка навіть зовні відрізняється від простої кількістю даних. Розв'язання обох задач представлено у таблиці 2 . 
Розв'язання обох задач

\begin{tabular}{|l|l|}
\hline \multicolumn{1}{|c|}{ Перша задача } & \multicolumn{1}{|c|}{ Друга задача } \\
\hline 1) $8+5=13$ (авт.) & 1) $8-2=6$ (авт.) \\
2) $13-9=4$ (авт.) & 2) $8+6=14$ (авт.) \\
Відповідь: 4 автомобілям ще залишилося & Відповідь: 14 моделей автомобілів \\
оформляти документи. & було у Миколки. \\
\hline
\end{tabular}

Практика роботи вчителів засвідчує, що ними використовується два способи введення першої складеної задачі: утворення складеної задачі із двох простих, або використання готової складеної задачі. Враховуючи високий рівень розвитку індивідуально-психологічних особливостей та високий рівень математичної підготовки учнів класу, слід використати перший варіант ознайомлення із першою складеною задачею. Для цього використовується дві прості задачі, в яких відповідь до першої задачі є одним із даних у другій задачі. Пропонуємо дітям розв'язати дві задачі:

1) «На митницю приїхало для розмитнення 8 вантажних i 5 легкових автомобілів. Скільки всього автомобілів приїхало на митницю?»;

2) «На митницю приїхало для розмитнення 13 автомобілів. 9 автомобілів вже оформили всі необхідні документи. Скільком автомобілям ще залишилося оформляти документи?».

Після того, як діти розв'яжуть обидві задачі, пропонуємо їм скласти 3 двох задач одну, взявши повністю умову першої задачі, частину умови другої задачі (про кількість автомобілів, які оформили документи) і запитання другої задачі. Вислухавши запропоновані дітьми варіанти задач, вчитель повинен при потребі уточнити іiі: на митницю приїхало для розмитнення 8 вантажних і 5 легкових автомобілів. 9 автомобілів вже оформили всі необхідні документи. Скільком автомобілям ще залишилося оформляти документи?

Якщо не всі діти засвоїли умову задачі, то потрібно вивчити іiі, а потім перевірити, як вони іiї засвоїли. Наприклад, запропонувати кільком школярам повторити умову і запитання задачі, або поставити їм такі запитання: скільки вантажних автомобілів приїхало на митницю? - 8. Скільки легкових автомобілів приїхало на митницю? - 5. Скільки автомобілів оформили документи? - 9. Варто зазначити, що для заощадження місця подано короткі відповіді, але від учнів слід вимагати повних відповідей. Що необхідно визначити у задачі: кількість автомобілів, яким ще залишилося оформляти документи. Можна також використати на допомогу учням короткий запис умови задачі, який повинен 3'явитися на очах у дітей (а не в готовому вигляді!), і що представлений у таблиці 3 .

\section{Короткий запис умови задачі}

Таблиця 3

Приїхало на митницю 8 вантажних і 5 легкових автомобілів

Оформили документи 9 автомобілів

Залишилося ще оформляти документи - ?

Після того, як учнів ознайомлено 3 першою складеною задачею, розпочинається системна робота 3 формування в них уміння розв'язувати. Аналіз методичної літератури, вивчення досвіду роботи вчителів-новаторів 
дозволяє стверджувати, що 3 цією метою відповідно до індивідуальнопсихологічних особливостей школярів слід використовувати такі вправи:

1) складання умови до цього запитання, бо при його виконанні діти фактично проводять міркування, аналогічні з тими, 3 якими вони будуть зустрічатися при розв'язуванні складених задач (щоб визначити ..., потрібно знати ...). Для особистісної орієнтації навчального процесу вчитель відповідно до індивідуальних особливостей дітей повинен надавати їм необхідну допомогу у вигляді малюнка, наочної ілюстрації, заданого сюжету, опорних слів (на ... більше, у ... разів більше) тощо;

2) постановка запитання до цієї умови, наприклад: «На одній поличці стоїть 5 книг, а на другій - на 2 більше. Яке запитання можна поставити до такої умови, щоб скласти задачу?». При виконанні такого завдання здібним учням слід пропонувати поставити всі можливі запитання. Іншим дітям пропонується поставити запитання так, аби задача розв'язалася двома діями. Тим школярам, які не в змозі виконати зазначених завдань, вчитель повинен надати певну допомогу у вигляді опорних слів (наприклад: скільки всього ...) або провести з ними відповідну бесіду;

3) вправи на заміну запитання задачі. Наприклад, пропонуємо учням розв'язати наступне завдання «На майданчику гралося 4 дівчинки, а хлопчиків - на 3 більше. Скільки дівчаток гралося на майданчику?». Встановлюючи зв'язок запитання та умови задачі, діти виявляють, що у запитанні запитується про те, що вже подано в умові задачі. Після цього пропонується змінити запитання так, щоб відповісти на нього можна було після розв'язання задачі.

Для того, щоб формувати у дітей уміння обирати потрібну арифметичну дію, попереджувати помилки при виборі дій, сприяти формуванню уміння розв'язувати складені задачі, як свідчать результати вивчення досвіду роботи вчителів, слід частіше включати в усні вправи задачі-запитання, вправи на порівняння задач, що мають схожі формулювання, використовувати самостійну роботу при розв'язанні задач.

Аби допомогти дітям віднайти шлях розв'язання задачі, корисно, як свідчить досвід вчителів, використовувати частково виконане розв'язання, зразки міркувань, довідкові матеріали, вказівки, план розв'язання, пояснення до дії тощо. Так, наприклад, для задачі «В одній коробці було 12 фломастерів, а у другій - 9. 4 фломастери поклали у третю коробку. Скільки фломастерів залишилося у перших двох коробках?» можна запропонувати варіанти завдань, які представлені у таблиці 4.

Таблиця 4

Варіанти завдань

\begin{tabular}{|l|l|}
\hline \multicolumn{1}{|c|}{ І варіант } & \multicolumn{1}{|c|}{ IІ варіант } \\
\hline 1. Закінчи короткий запис задачі: & 1. Використовуючи опорні слова, запиши \\
Було -12 фломастерів $\mathrm{i} \square$ & задачу коротко: \\
Поклали в третю коробку $-\square$ & Було - \\
Залишилось у перших двох $-\square$ & Поклали в третю коробку \\
2. Використовуючи схему, запиши & Залишилось у перших двох \\
розв'язання задачі: & 2. Запиши виразом, скільки фломастерів \\
$(\square * \square) * \square=\square$ & було у двох коробках: \\
3. Запиши відповідь. & 3. Закінчи розв'язання задачі: \\
& $(12+\square)-$ \\
& 4. Запиши відповідь. \\
\hline
\end{tabular}




\begin{tabular}{|c|c|}
\hline III варіант & IV варіант \\
\hline $\begin{array}{l}\text { 1. Розв'яжи задачу, склавши до неї } \\
\text { вираз. } \\
\text { 2. Запиши відповідь. } \\
\text { 3.Запиши інші способи розв'язання } \\
\text { цієї задачі. }\end{array}$ & $\begin{array}{l}\text { 1. Запиши всі можливі способи розв'язання } \\
\text { цієї задачі. } \\
\text { 2. Запиши відповідь. } \\
\text { 3. Запиши, яким буде розв'язання задачі, } \\
\text { якщо у третю коробку перекладуть } 14 \\
\text { фломастерів. }\end{array}$ \\
\hline
\end{tabular}

Опрацювання методичної літератури, експериментальні дослідження свідчать, що $є$ учні, для яких процес формування уміння розв'язувати задачу проходить значно швидше, якщо вони володіють умінням розбивати задачу на смислові частини. Аби цього досягти цього, варто використовувати такі завдання:

1) на розбиття текстів кількох задач на смислові частини;

2) на визначення правильності виділених смислових частин у цій задачі 3 наступним встановленням питання чи допомагають вони розв'язувати задачу;

3) на порівняння двох однакових задач, які розбиті на смислові частини по-різному, з'ясовуючи, який з них допомагає розв'язувати задачу;

4) на повторення тексту задачі, яку прочитав вчитель, за смисловими частинами;

5) на взаємоперевірку розбиття тексту задачі на смислові частини; тощо.

Висновки і перспективи подальших розвідок. Розв'язування сюжетних задач $\epsilon$ не тільки важливим засобом формування в учнів математичних компетентностей, але й засобом підготовки учнів до розв'язування практичних завдань через моделювання, через показ ролі математики у житті людини. У зв'язку із вимогами Державного освітнього стандарту початкової школи подальших розвідок вимагають проблеми підготовки майбутніх вчителів початкової школи до реалізації завдань компетентнісного підходу.

\section{СПИСОК ВИКОРИСТАНИХ ДЖЕРЕЛ:}

Міністерство освіти і науки України, (2018). Навчальні програми для загальноосвітніх навчальних закладів із навчанням украйнської мовою. 1-4 класи.

Богданович, М., Козак, М. та Король, Я. (2008). Методика викладання математики в початкових класах. 3-є вид. Тернопіль: Навчальна книга - Богдан. $336 \mathrm{c}$.

Богданович, М. (1990). Методика розв'язування задач у початковій школі. 3-е вид. Київ: Рад. Шк.183 с.

Богданович, М., Будна, Н., та Лишенко, Г. (2004). Урок математики в початковій школі. Тернопіль: Навчальна книга - Богдан. 280 с.

Коваль, Л. та Скворцова, С. (2011). Методика навчання математики: теорія і практика. 2-ге вид. Харків: ЧП «Принт-Лідер». 414 с.

Скворцова, С. (2006). Методична система розв'язування сюжетних задач учнів початкових класів. Одеса: Астропринт. 696 с.

Сюжетні задачі, що містять сталу величину: 3-4 класи. (2013) . Київ: Редакції газет з дошкільної та початкової освіти.

Скворцова, С. (2013). Підготовка майбутніх вчителів початкових класів до навчання молодших школярів розв'язувати сюжетні математичні задачі. Харків: «Ранок-НТ». $332 \mathrm{c}$.

Скворцова, С. Методика навчання математики в 1-му класі. Одеса: Фенікс. $240 \mathrm{c}$. 
Скворцова, С. (2012). Методика навчання математики в 2-му класі. Харків: Видавництво «Ранок». 112 с.

\section{REFERENCES:}

Ministerstvo osvity i nauky Ukrainy. (2018). Navchalni prohramy dlia zahalnoosvitnikh navchalnykh zakladiv iz navchanniam ukrainskoi movoiu. 1-4 klasy. [Curriculums for General Educational Institutions with Ukrainian Language of Teaching. Grades 1-4.] [in Ukrainian]

Bohdanovych, M., Kozak, M. ta Korol, A. (2008). Metodyka vykladannia matematyky v pochatkovykh klasakh. [Methodology of Teaching Mathematics in Primary School] 3-ye vyd. Ternopil: Navchalna knyha - Bohdan. 336 s. [in Ukrainian]

Bohdanovych, M. (1990). Metodyka rozviazuvannia zadach u pochatkovii shkoli. [Methodology for Solving Sums in Primary School] 3-e vyd. Kyiv: Rad. Shk.183 s. [in Ukrainian]

Bohdanovych, M., Budna, N. ta Lyshenko, H. (2004). Urok matematyky $v$ pochatkovii shkoli.[Maths Lesson in Primary School] Ternopil: Navchalna knyha Bohdan, $280 \mathrm{~s}$. [in Ukrainian]

Koval, L. Ta Skvortsova, S. (2011). Metodyka navchannia matematyky: teoriya $i$ praktyka. [Methodology of Teaching Mathematics: Theory and Practice.] 2-he vyd. Kharkiv: ChP "Prynt-Lider". 414 s. [in Ukrainian]

Skvortsova, S. (2006). Metodychna systema rozviazuvannia siuzhetnykh zadach uchniv pochatkovykh klasiv. [Methodical System for Solving the Subject Sums of Primary School Students.] Odesa: Astroprynt. 696 s. [in Ukrainian]

Siuzhetni zadachi, shcho mistiat stalu velychynu: 3-4 klasy. [Subject Tasks that Contain a Constant Value: 3-4 drades] (2013). Kyiv: Redaktsii hazet z doshkilnoi ta pochatkovoi osvity. $128 \mathrm{~s}$. [in Ukrainian]

Skvortsova, S. (2013). Pidhotovka maibutnikh vchyteliv pochatkovykh klasiv do navchannia molodshykh shkoliariv rozviazuvaty siuzhetni matematychni zadachi. [Training of Future Primary School Teachers to Teach Junior Students to Solve Subject Mathematical Sums.] Kharkiv: "Ranok-NT", 2013. - 332 s. [in Ukrainian]

Skvortsova, S. (2011). Metodyka navchannia matematyky $v$ 1-mu klasi. [Methodology of Teaching Mathematics in the 1-st form] Odesa: Feniks. 240 s. [in Ukrainian]

Skvortsova, S. (2012). Metodyka navchannia matematyky $v$ 2-mu klasi. [Methodology of Teaching Mathematics at the 2-nd Grade] Kharkiv: Vydavnytstvo "Ranok", 2012. - 112 s. [in Ukrainian]

\section{THEORETICAL AND METHODOLOGICAL BASES OF THE FORMATION OF GENERAL METHODS OF WORK WITH SUBJECT SUMS IN FUTURE ELEMENTARY SCHOOL TEACHERS}

Elvira Silkova

Senior Lecturer at the Department of Mathematics with Teaching Methodology Rivne State University of the Humanities,

Rivne, Ukraine

ORCID:0000-0002-2595-0606 e-mail: esilkova69@gmail.com

\footnotetext{
Abstract. In the article on the basis of the new edition of the "Curriculum for general educational institutions" the important role of the content line "Subject sum" in the process of teaching Mathematics is justified. The purpose of this content line is to form in students the general ability to work on a task, to solve tasks of certain types. It has
} 
been established that subject sums are an effective means of teaching and developing students. The tasks in the initial course of Mathematics, on the one hand, are a specific section of the program that students have to learn, and on the other hand, they act as a didactic tool for the education and development of schoolchildren. Thus, the sums allow to simulate practical situations, to show the connection of mathematics with life.

The article deals with the theoretical and methodological basis of the formation of general methods of work on the subject sums tasks in future teachers of primary school. In order to avoid shortcomings in the formation of the ability to solve sums it is proposed to adhere to the following stages of work on any sum: 1) to get students to know the tasks of the sum; 2) verification of student learning of the content of the task; 3) analysis of the problem or finding ways to solve it; 4) drawing up a plan for solving the problem; 5) explanation the solution to the sum; 6) work on a solved sum. Each stage of work on sum is analyzed. Schemes of analytical and synthetic methods for analyzing tasks are illustrated. By the example of the sum, the essence of the teacher's work is demonstrated using various methods of its analysis. The explanations of short conditions of sums and various ways of their solution are presented, as well as a system of exercises on the formation of skills to solve the subject sums.

Key words: task, stages of work on the sum, short condition, analytical and synthetic methods of problem analysis, scheme, sum solution plan, solution.

Стаття надійшла до редакиії 03.04.2019p. 